\title{
УДК 316.25
}

\section{ПОНЯТТЯ «НАСИЛЬСТВО»В СОЦІОЛОГІЧНОМУ ДИСКУРСІ: КРИТИЧНА ТРАДИЦІЯ}

Бойко Дмитро Миколайович - старший викладач кафедри політичної соціології соціологічного факультету Харківського національного університету імені В. Н. Каразіна, майдан Свободи, 4, Харків, 61022, Україна, e-mail: dmitry.n.boyko@gmail.com, ORCID https://orcid.org/0000-0003-3425-8555

Boiko Dmytro - Senior Lecturer, Department of Political Sociology V. N. Karazin Kharkiv National University, 4 Svobody sq., Kharkiv, 61144, Ukraine, e-mail: dmitry.n.boyko@gmail.com, ORCID https://orcid.org/0000-0003-3425-8555

У статmі здійснюється аналіз соціологічної рефрлексії френомену насильства з точки зору їі концептуального і світоглядного різноманіття. Наводиться класифрікація підходів до вивчення насильства в соціології, побудована з огляду на співвідношення насильства та соціальності: були виокремлені апологетична та критична традиції в соціологічному дискурсі насильства. При цьому автором акцентується увага на процесі проблематизації символічного насильства у критичній традиції соціологічного теоретизування. у контексті цієї традиції детально розглядаються концепції К. Маркса та Ф. Енгельса, А. Грамші, Н. Еліаса та М. Фуко з точки зору їхнього внеску в розвиток соціології насильства. Автор розкриває те, як у фрарватері критичної традиції розвивається ідея про складність та багатовимірнсть природи насильства, що виключає можливість зведення його лише до фрізичного, тому постає необхідність виділення й інших видів та фрорм насильства - символічного, психологічного, структурного тощо; у статті основна увага зосереджена на підвалинах концепту символічного насильства. Формулюється висновок про те, що у понятті «символічне насильство» поєднується цілий пласт критичних гносеологічних конструктів, як-от «панування», «відчуження», «експлуатація», «гегемонія», «боротьба», «істеблішмент та аутсайдери» та інші. Критичний потенціал поняття «символічне насильство» вбачається, по-перше, у можливості деконструкції очевидного та повсякденного з метою пошуку втілення у ньому владних відносин, по-друге, у виділенні інтересів певної групи людей у звичних та рутинних відносинах підпорядкування та панування, сконцентрованих у структурах повсякденності.

Ключові слова: насильство, символічне насильство, соціологія насильства, критична соціологія.

The article is devoted to the analysis of sociological reflection of the phenomenon of violence in terms of its conceptual and ideological diversity. The classification of approaches to the study of violence in sociology, based on the relation of violence and sociality, is proposed: apologetic and critical traditions are identified in the sociological discourse of violence. The process of problematization of symbolic violence in the critical tradition of theorizing is studied. The concepts of K. Marx and F. Engels, A. Gramsci, N. Elias and $M$. Foucault are considered in detail from the point of view of their contribution to the sociology of violence in general. The author reveals how in the formation of the critical tradition the idea of the complexity and multidimensionality of the nature of violence develops, which excludes the possibility of reduction of the violence only to the physical one; therefore, therefore it is necessary to distinguish the other forms and types of violence - symbolic, psychological, structural, etc; the article focuses on the problem of the foundation of the concept of symbolic violence. The author comes to the conclusion that the concept of "symbolic violence» combines a variety of critical epistemological constructs, such as "domination», "alienation», "exploitation», "hegemony», "struggle», "establishments and outsiders» and others. The critical potential of the concept of «symbolic violence» lies, firstly, in the possibility of deconstruction of the obvious and everyday structures in order to find an embodiment of power relations, and secondly, in the allocation of interests of a certain group of people in the usual and routine relations of subordination and domination, concentrated in structures of everyday life.

Keywords: violence, symbolic violence, sociology of violence, critical sociology.

Критика, безусловно, способна загубить любую мысль. П1. Капиц̧a

У соціологічних та соціально-філософських дисциплінах існує велика кількість підходів до розуміння феномену насильства, і всі вони мають чимало відмінностей і протиріч. Це і принципово різні дефініції поняття «насильство», і взаємовиключні класифікації, і відмінні способи концептуалізації, i навіть парадигмальні розколи. Проте, на нашу думку, фундаментальне протиріччя у полі соціологічної рефлексії насильства криється не на рівні ідей, концепцій чи теорій, а на рівні світоглядів. Саме навколо відмінностей у світосприйнятті формується основне «роздоріжжя» у соціологічному теоретизуванні щодо феномену насильства. Адже в залежності від того, як саме сприймати насильство - як «збій» соціальної

(C) Бойко Д. М., 2018

DOI: 10.26565/2227-6521-2018-41-04 
системи чи як невід'ємний ії елемент, і вибудовується наукова картина світу, деталізована в певних концепціях, категоріях, операціоналізаціях та індикаторах.

Крім того, з онтологічної точки зору ми спостерігаємо широко розповсюджене протистояння дискурсів та інтерпретацій насильства як суто «дискомфортного», «засуджуваного», «неприємного» процесу або як об'єкту конструювання, коли насильством називається те, що самим об'єктом насильства (групою чи людиною, що знаходиться під «ударом» насильства) не інтерпретується як таке. Перша тенденція призводить до того, що М. Фуко називає «тоталітаризмом всередині нас», коли люди ігнорують насправді насильницькі дії та структури відносно себе, відмовляючись сприймати їх у категоріях насильства. Друга тенденція призводить до гіперактуалізації різноманітних образ, поведінки ображених груп (ображених, наприклад, вживанням не-фемінітивів чи, навпаки, фемінітивів).

Усе розмаїття соціологічних теорій насильства ми пропонуємо розглянути з точку зору однієї достатньо простої та умовної класифікації, а саме класифікації за ознакою співвідношення насильства та соціальності, виділяючи апологетичну та критичну традиції. Перша розглядає насильство у його протиставленні до «нормальних» суспільних відносин, інтерпретуючи насильство за допомоги категорій «девіація», «аномія», «легітимність-нелегітимність», «легальність-нелегальність» тощо. Тоді як остання йде шляхом пошуку неочевидного в очевидному, зосереджуючи увагу на виявленні насильства у «нормальному» соціальному житті. Саме тому в рамках критичної традиції відбувається проблематизація «символічного насильства» $[1 ; 2]$, яке структурно є суто насильницьким, але без очевидних віктимних проявів.

3 огляду на зазначене вище, метою цієї статті є 3'ясування ролі та місця критичної традиції у еволюції соціологічного дискурсу насильства. Дослідивши процес становлення соціологічного вивчення насильства, ми спробуємо визначити, чому проблематизація символічного насильства мала місце саме в критичній традиції і які концепції та ідеї втілилися та поєдналися в цьому понятті.

Реалізуючи цю мету, перш за все зазначимо, що критичний підхід до розуміння феномену насильства сходить до діалектики «раба» і «пана» Г.В.Ф. Гегеля, котрий на цих метафорах демонструє те, як він уявляє історичний процес саморозвитку: коли дві людини знаходяться одна перед одною, то між ними виникає напруженість, тому що кожен з них хоче, щоб інша визнала ії володарем ситуації (тобто тим, хто визначає себе та іншого) [3]. Виходячи з цієї моделі, Г. Гегель і пояснює історичний процес боротьбу за визнання, у якій одна людина буде підпорядкована іншій. В підсумку виникає ситуація, в якій $\epsilon$ домінуючий, «пан», і підпорядкований («раб»). «Пан» змушує «раба» працювати на нього, в результаті чого відбувається взаємний розвиток, за якого людина («раб») культивує природу, яка, у свою чергу, змінює людину. В процесі обробки «рабом» поля створюється матеріальний надлишок, який забезпечує основу для появи більш ефективних прийомів праці та кращих знарядь, що призводить до подальшого культивування природи та саморозвитку людини («раба»).

Така модель представляє діалектичний процес, що розгортається між людиною (суб'єктом) i природою (об'єктом). У цьому процесі «раб» знаходиться ближче до реальності i, отже, дізнається більше (саме «раб», на думку Г. Гегеля, стає вченим), тоді як «пан» виступає в ролі необхідного каталізатора. Г. Гегель вважає, що таким чином він подолав кантівську статичну відмінність суб'єкта та об'єкта, при якій суб'єкт ніколи не сягає об'єкта. «Відносини пан-раб є одночасно діалектичним зв'язком у тому сенсі, що між цими двома суб'єктами існує внутрішня динамічна взаємодія. Пан $є$ паном тільки тому, що раб (і сам пан) визнає його як пана. Відповідно, раб настільки раб, наскільки пан (i сам раб) визнає його як раба» [9, с. 509].

Ця модель не просто стверджує наявність насильства в соціальності, вона говорить про нього як про один із фундаментальних механізмів історичного процесу. До речі, для Г. Гегеля сама історія починається 3 того, що «кочівники» завойовують «хліборобів». Доробок гегелівського ідеалізму в концептуальному плані $\epsilon$ відносно «сирим» і не має прямого застосування у соціологічній науці, проте дає нам два важливих моменти для наукового світогляду: по-перше, це процесуально-діалектична картина світу як єдності і боротьби протилежностей; по-друге, це пошук неочевидного в очевидному, спроба «копнути глибше». I така логіка прослідковується в творчості всіх учених, котрих ми віднесли до критичної традиції.

Найбільш яскравим послідовником Г. Гегеля, а також «батьком» критичної парадигми в соціології є Карл Генріх Маркс. Теорія насильства у К. Маркса надзвичайно багатогранна. По-перше, власне фізичне «насильство $\epsilon$ повитухою будь-якого старого суспільства, коли воно вагітне новим» [6, с. 761]. Саме ескалація насильства (перш за все у вигляді революції) є шляхом переходу від однієї суспільноекономічної формації до іншої.

По-друге, «насильство - це економічна потенція» [там само], тобто воно виступає формою відносин у сфері суспільного виробництва. Насильство є однією з форм примусу, зокрема примусу до праці (i, як наслідок, - відчуження). «Фабрики рекрутують своїх робітників, як і королівський флот своїх матросів, за допомоги насильства» [6, с. 767]. У ХІХ столітті цю фразу можна (і потрібно) було сприймати буквально, але в наш час (завдяки реальним та сумнівним досягненням трудового законодавства) форму насильства слід уточнювати. 
По-третє, насильство є атрибутом держави. У цьому сенсі основоположники марксизму були послідовниками Т. Гоббса, який бачив у системі політичної влади Левіафана - чудовисько, що підкорює людей (але одночасно забезпечує їм безпеку). Однак відмінність К. Маркса від Т. Гоббса полягає у тому, що для першого воно підпорядковано інтересам певного класу, а з точки зору другого, державне насильство підпорядковане вирішенню завдань «спільного» блага та/або обслуговуванню інтересів конкретного правителя. Для Ф. Енгельса, який написав про державу більше, ніж К. Маркс, очевидним є те, що держава є системою насильства, вона авторитарна за своєю природою. Ії̈ завдання полягає в тому, щоб змусити одну частину суспільства виконувати рішення, прийняті іншою частиною суспільства, тому держава створює суто авторитарні збройні сили, а також бюрократію та правову систему, які авторитарні тією ж мірою [13].

По-четверте, розкриваючи історичність і, відповідно, конечності держави, класичний марксизм акцентує на інтересах класу експлуататорів, які реалізуються за допомоги насильства. В сучасному для К. Маркса і Ф. Енгельса світі це був (і залишається до сьогодення) клас буржуазії. Свого часу цей клас скористався (відповідно до першого пункту) цим засобом для здійснення соціальної революції: «Всі вони [західноєвропейські буржуа XVII ст.] користуються державною владою, таким чином концентрованим i організованим суспільним насильством, щоб прискорити процес перетворення феодального способу виробництва на капіталістичний і скоротити його перехідні стадії» [6, с. 761], а при досягненні цієї мети переспрямувати цей засіб на утримання існуючої капіталістичної формації.

П'ятим i найважливішим для нас пунктом інтерпретації класичного марксизму у контексті проблематики нашого дослідження є концепція класової боротьби. Навіть не стільки класової боротьби, скільки просто боротьби. Це світоглядна установка, яка передбачає, що в основі будь-якої соціальної (взаємо)дії, будь-якого соціального процесу лежить боротьба, тобто протистояння сил. Тим не менше, в ортодоксальному марксизмі саме насильство трактується буквально, тобто як фізичне («завоювання, поневолення, розбій» [6, с. 726]), воно застосовується, коли «надбудова» не справляється у своїх потугах 3 примусу класу експлуатованих (з метою руйнування формації - революція, або 3 метою їі підтримки реалізація функцій силових структур держави). Інші форми протистояння сил (що мають насильницьку природу, але не мають прямого фізично-руйнівного втілення) класичний марксизм оминає і залишає на розгляд своїм послідовникам.

Одним 3 цих послідовників, що висунув ряд важливих зауважень до вивчення феномену насильства, був Антоніо Грамші. Уникаючи тюремної цензури ${ }^{1}$, яка не пропускала термінологію К. Маркса та Ф. Енгельса, А. Грамші переінакшував багато марксистських термінів, зберігаючи їхній зміст. Так народилася його теорія гегемонії [5]. Поняття «гегемонія» майже тотожне поняттю «панування» (у традиції К. Маркса), проте А. Грамші уточнює, що гегемонія заснована на формуванні згоди. Для соціолога найбільш значущим питанням у даному випадку є те, якими засобами досягається згода у взаємодії класів, бо вона не є чистою згодою через свою асиметричну природу. Суть гегемонії як морального, інтелектуального і політичного панування над суспільством полягає в тому, що свідомість панівного класу, його світогляд, його ідеали сприймаються суспільством як справедливі, істинні, універсальні, як загальний здоровий глузд. Універсальність та «обов'язковість» картини світу, що нав’язується, втілює тотальне насильство, яке неможливо помітити, будучи під його впливом.

Звідси другий важливий теоретико-методологічним інструмент теорії А.Грамші - поняття «маніпуляціяя. Феномен, що позначається цим терміном, є одним 3 найбільш потужних засобів впливу політичних суб'єктів на політичне середовище, який передбачає формування у представників політичного середовища цілісної (але не пов'язаної з дійсністю) картини політичного світу. При маніпуляції ця картина світу формується не самостійно, а привноситься ззовні; вона містить у собі низку вигідних для правлячого класу аксіом та ряд переінакшених трактувань, що не підлягають перевірці. Наслідуючи ідеї «Німецької ідеології», де зазначається, що «будь-який новий клас, що ставить себе на місце класу, що панував до нього, вже для досягнення своєї мети змушений представити свій інтерес як загальний інтерес усіх членів суспільства» [7, с. 47], тобто представити свої думки «як єдині розумні, загальнозначущі», А. Грамші пише, що панівний клас для утримання свого панування постійно підтримує цю ілюзію загальної значущості, справедливості свого способу життя, способу мислення [5]. Наприклад, буржуазія, заперечивши феодальний лад, висунула гасла свободи, рівності і братерства як загальнолюдські.

Для нас теорія А. Грамші цікава тим, що вона заповнює ту порожнечу, яка залишалася в теорії Маркса щодо нефізичного насильства. Італійський теоретик зауважує, що панування (гегемонія) формуються не (с)тільки за допомоги фізичного насильства і примусу, а й за допомоги формування відповідної культури. Характеристики такої культури сформулював інший представник критичної традиції (немарксистського за методологією підходу) - Норберт Еліас. Веберіанське теоретико-

\footnotetext{
${ }^{1}$ За свою політичну позицію і революційну діяльність А. Грамші був засуджений і засланий на острів Устіка в тюремне ув'язнення, де і написав майже три тисячі сторінок, що склали ядро його творчої спадщини - знамениті «Тюремні зошити» [5].
} 
методологічне коріння концепції Еліаса пов'язує його з апологетичним підходом: «показовою є позиція Еліаса щодо держави (тут він спирається на веберівську дефініцію держави як монополії на легітимне фізичне насильство)» [4, с. 30]. Проте, на відміну від М. Вебера, Н. Еліас достатньо чітко розумів як історичність самого явища держави, так і контекстуальність будь-яких власних відносин. Яскравим прикладом такого бачення є його робота у співавторстві з Дж. Л. Скотсоном «Істеблішмент і аутсайдери» [14], де вони презентували емпіричний аналіз стилю життя двох груп одного англійського містечка істеблішменту та аутсайдерів. Під істеблішментом автори розуміють групу, яка характеризується надлишком влади відносно іншої групи, тобто відносно аутсайдерів; причому влада істеблішменту здійснюється, крім силових засобів, ще й засобами ідеології. Саме цей аспект нас цікавить найбільше.

Домінуюче положення істеблішменту грунтується, зокрема, на так званій «груповій харизмі» (де знову відчувається вплив М. Вебера), тобто на низці приписаних унікальних якостей, які, з одного боку, звеличують цей самий істеблішмент, а, з іншого - принижують аутсайдерів. Це формує в останніх почуття неповноцінності, соціально-психологічні наслідки якого втілюються в значеннях, комунікативних практиках i символах (наприклад, в таких бінарних опозиціях, як «висока культура - низька культура», «високе походження - низьке походження», стереотипи про витонченого аристократа, джентльмена і т.д. та грубого селянина чи брудного люмпена, людяного християнина і підступного єврея). Групова харизма істеблішменту створюється на основі «кращих якостей» іiі «кращих» представників, а груповий портрет аутсайдерів створюється на основі «гірших» якостей «поганої» частини цієї групи. Створене ж штучне «тавро» для представників групи аутсайдерів стає елементом ідентифікації, що робить їхнє становище ще менш привабливим.

Початковим моментом і серцевиною у фігурації істеблішменту і аутсайдерів $є$ нерівний баланс влади між соціальними групами. Перевага істеблішменту базується на різних джерелах влади: для істеблішменту, як ми вже згадували, це «групова харизма», яка досягається згуртованістю групи, наявністю внутрішньогрупового контролю, колективної ідентифікації та загальних норм. Так встановлюється i підтримується закритість групи, можливість контролювати вхід до групи і розподіл монополізованих групою ресурсів. Але якщо істеблішмент втрачає свою монополію на владу і баланс влади зміщується в іншу сторону, то колишні аутсайдери починають завойовувати нові позиції, стигматизувати істеблішмент, відділятися від нього, монополізувати владні ресурси, тим самим міняючись 3 ним місцями.

До аналізу дискурсивних та символічних аспектів конструювання домінування та підпорядковування звертається ще один представник немарксистської (з точки зору методології) гілки критичної традиції - Мішель Фуко, який співвідносив насильство та владу, але з (пост)структуралістських позицій. Його роботи можна без перебільшення вважати одними 3 найбільш яскравих у соціології насильства. Це зумовлюється, з одного боку, його історіографічним аналізом засобів і способів реалізації покарання (загадаємо перший розділ його книги «Наглядати і карати»), а з іншого - запропонованим ним баченням соціальності насильства.

У вже згаданій роботі [12] М. Фуко розглядає еволюцію політичних технологій західного суспільства при переході від епохи феодалізму до сучасності. Зазначимо, що в середині XVIII століття для влади була характерна жахлива за сучасними мірками жорстокість, але вже в 30-ті роки XIX століття влада стала більш «м'якою» і «гуманістичною». Якщо раніше злочинців публічно страчували або піддавали тортурам, то пізніше їх стали поміщати під ретельний тюремний нагляд, що виключає будь-яке насильство над тілом. Тобто змінилася сама соціальна логіка покарання: суб'єктом злочину (i, відповідно, об’єктом покарання) перестає бути тіло злочинця, ним стає його душа. Відповідно, покарання, реалізоване за допомогою насильства, перестає носити фізичний характер, втілюючись у нефізичному - символічному.

Більше того, жорстокість публічних страт минулої епохи не давала реалізуватися новій ідеологічній концепції - профілактиці злочинів (по суті, старти мали зворотній ефект - навчали жорстокості, прирівнювали ката до злочинця, а суддів - до вбивць). 3 появою гільйотини сцени страти, втративши свою видовищність, набули раціонально-дидактичного змісту. Тюремне ж ув'язнення стає і способом примусової нормалізації індивідів, і засобом залякування потенційних злочинців (найбільш яскраво це втілюється в ідеї Паноптикума - прозорого для зовнішнього спостерігача, але закритого для ув'язнених простору).

Влада в концепції М. Фуко перестає бути власністю того чи іншого класу, яку можна захопити або передати, вона не локалізується в одній тільки надбудові, в державному апараті, а поширюється по всьому соціальному полю, пронизує все суспільство, охоплюючи як пригнічених, так і тих, хто пригнічує [11]. Влада реалізує репресивну та ідеологічну функції, але не вичерпується ними, вона становить дещо більше: «влада виробляє, і виробляє вона реальність» [12, с. 284]. До того, як щось придушувати, вона спочатку це продукує (в інших роботах М. Фуко розглядає це на прикладі генези божевілля, сексуальності тощо).

Влада існує не тому, що існує держава або державні інститути (суд, поліція, армія тощо), а навпаки, вони є породженням або втіленням влади. Перестаючи бути інституційно локалізованою, влада стає анонімною, невизначеною і невловимою: «Влада всюди, але не тому, що вона охоплює все, а тому, що виникає звідусіль» [10, с. 195]. Вона розсіюється на безліч «осередків» і «коліщаток», система яких 
утворює «діаграму механізму влади», що нагадує якусь досить тонку i гнучку сітку. Влада репрезентується нам як абстрактна машина, схожа на perpetuum mobile, робота якого не потребує допомоги з боку людини. Втілення влади в окремо взятій людині є реалізацією дисциплінарної влади, внутрішньої структури (само)контролю, що укорінена в самому тілі.

Найбільш глибокий зв'язок влада має зі знанням. Розвиваючи відому ідею Ф. Ніцше про невіддільність «волі до влади» від «волі до знання», М. Фуко підсилює іiі і доводить до крайності, розглядаючи владу в дусі своєрідного «панкратизму» (всевладдя). «Жодне знання, - зазначає він, - не формалізується без системи комунікацій, яка сама по собі вже є формою влади. Жодна влада не здійснюється без продукування, присвоєння, розподілу та приховування знання» [8, с. 190]. Немає відносин влади без корелятивного утворення поля знання, як немає знання, яке в той же час не передбачає і не утворює відносини влади. Взаємозв'язок знання і влади демонструє така формула: влада встановлює знання, яке, у свою чергу, виступає гарантом влади. Вирішальною в історії відносин між знанням і владою $\epsilon$ остання, вона «робить можливими і продукує ці виробництва істин, а ці виробництва істин самі здійснюють власні дії, котрі нас зв'язують та обмежують» [11, с. 286 ], інша влада - інше знання.

Так, знання, будучи, в тому числі, можливістю сприйняття і дешифровки культурних кодів, знаків i символів, виступає засобом (від)творення влади 3 боку самої влади. Якщо виходити 3 суто структуралістського розуміння М. Фуко і доповнити його концепцію ідеями агентності (поставити за лаштунки влади трансцедентального актора), то знання стає результатом символічного насильства для підтримки владних відносин. Саме цю ідею вже опрацював П. Бурдьє, у творчості якого виділяється i проблематизується феномен символічного насильства як невід'ємного атрибуту соціальних взаємодій у сучасному світі. Тим самим у понятті «символічне насильство» поєднується цілий пласт таких критичних гносеологічних конструктів, як «панування», «відчуження», «експлуатація», «гегемонія», «боротьба», «істеблішмент та аутсайдери» тощо.

Звичайно, здійснений нами та представлений вище аналіз соціологічного дискурсу насильства не охоплює все різноманіття тематичних концепцій та концептів: насамперед, окремої уваги потребують у цьому контексті концепція уречевлення та класової свідомості Д. Лукача, негативна діалектика М. Хоркхаймера та Т. Адорно, фрейдомарксистська інтерпретація відчуження Е. Фромма, концепція одномірної людини Г. Маркузе, концепція ідеології Л. Альтюсера та ін. Наша увага була зосереджена на основних, як уявляється, найбільш значущих теоретичних підвалинах концепції символічного насильства.

Підводячи підсумки нашого аналізу критичної традиції в соціологічному дискурсі насильства, підкреслимо, що сутність цієї традиції, власне іiі критичність полягає у деконструкції апологетичних ідей соціальності, держави i влади та «звинуваченні» вищезазначених структур у притаманному їм насильницькому підгрунті. По-перше, представники цього підходу вбачають інтерес певної групи людей в існуючих відносинах підпорядкування та панування. По-друге, влада та насильство, боротьба та насильство, панування та насильство нерозривно пов'язані. По-третє, природа насильства є надто складною, щоб зводити його лише до фізичного, тому постає необхідність виділення й інших видів та форм насильства - символічного, психологічного, структурного тощо. Саме у генезі критичної традиції прослідковується поступове виокремлення символічного насильства, яке є атрибутом таких процесів та явищ, як боротьба (соціальна, класова, символічна), відчуження та експлуатація, реіфікація та фетишизація, панування та гегемонія, дискурсивна та дисциплінарна влада, легітимація та натуралізація тощо. Проаналізувавши теоретико-методологічні та критико-соціологічні підвалини концепту символічного насильства, ми дійшли висновків, що у подальших наших дослідженнях слід зосереджувати увагу на концептуалізації та емпіричному вивченні символічного насильства як специфічного процесу.

\section{Література:}

1. Бойко Д., Цымбалюк В. Символическое насилие: концептуализация и операционализация понятия. Соціологія у (пост)сучасності. Збірник тез доповідей XIII Всеукраїнської наукової конференції студентів та аспірантів (м. Харків, 23-24 квітня 2015 р.). Х.: ХНУ імені В. Н. Каразіна, 2015. С. 19-21.

2. Бойко Д. Н. Символическое насилие как объект социологического исследования: категоризация и операционализация. Вісник ХНУ імені В. Н. Каразіна. Серія «Соціологічні дослідження сучасного суспільства: методологія, теорія, методи», 2017. №37. Х.: ХНУ імені В. Н. Каразіна, 2017. С. 91-95.

3. Гегель Г. В. Ф. Феноменология духа. М.: Наука, 2000. 495 с.

4. Голиков А. С. Норберт Елиас в знаниевом дизайне: возможности исследования социального. Вісник Харківського національного університету імені В. Н. Каразіна. Серія «Соціологічні дослідження сучасного суспільства: методологія, теорія, методи», 2016 р. №36 С. 27-36.

5. Грамши А. Избранные произведения / пер. с итал.; под общ. ред. И. В. Григорьевой и др.; вступит. статья Г. П Смирнова; примеч. И. В. Григорьевой, К. Ф. Мизиано. М.: Политиздат, 1980. 422 с.

6. Маркс К., Энгельс Ф. Капитал. Сочинения в 23-т. М.: Государственное издательство политической литературы, 1960. T.1. $900 \mathrm{c}$.

7. Маркс К., Энгельс Ф. Немецкая идеология. Сочинения в 3-х т. М.: Государственное издательство политической литературы, 1947. Т.1. С. 9-454. 
8. Миронов В. В. Философия: Учебник для вузов М.: Инфра-М, 2005. 673 с.

9. Скирбекк Г., Гилье Н.. История философии / пер с англ. В. И. Кузнецова, под ред. С. Б. Крымского. М.: ВЛАДОС, 2003. $800 \mathrm{c}$.

10. Фуко М. Воля к истине: по ту сторону знания, власти и сексуальности / пер. с франц., комм. и послесл. С. Табачниковой. М.: Касталь, 1996. 448 с.

11. Фуко М. Интеллектуал и власть: Избранны политически статьи, выступления и интервь / пер. с франц. Б. М. Скуратов под общ. ред. В. П. Большакова. М.: Праксис, 2006. 320 с.

12. Фуко М. Надзирать и наказывать. Рождение тюрьмы / пер. с фр. М.: Ad Marginem, 1999. 480 с.

13. Энгельс Ф. Происхождение семьи, частной собственности и государства. Маркс К., Энгельс Ф. Избранные произведения. В 3-х т. Т. 3. М.: Политиздат, 1986. С. 28-178.

14. Elias N., Scotson J. L. The Established and the Outsiders. New York, 1994. 199 p.

Понятие «насилие» в социологическом дискурсе: критическая традиция

Статья посвящена анализу социологической рефлексии френомена насилия с точки зрения ее концептуального и мировоззренческого разнообразия. Приводится классификация подходов к социологическому изучению насилия, построенная на основе соотношения насилия и социальности: выделяются апологетическая и критическая традиции в социологическом изучении насилия. Исследуется процесс проблематизации символичного насилия в критический традиции теоретизирования. Подробно рассматриваются концепции К. Маркса и Ф. Энгельса, А. Грамши, Н. Элиаса и М. Фуко с точки зрения их вклада в социологию насилия вообще и выделение концепта символичного насилия в частности. Автор приходит к выводам, что в понятии «символическое насилие» сочетается целый пласт критических гносеологических конструктов, таких как "господство», «отчуждение», "эксплуатация», «гегемония», "борьба», "истеблишмент и аутсайдеры» и другие. Его критический потенциал кроется, во-первых, в возможности деконструкции очевидного и повседневной с целью поиска воплощения в нем властных отношений $u$, во-вторых, выделении интересов определенной группы людей в привычных и рутинных отношениях подчинения и господства, сконцентрированных в структурах повседневности.

Ключевые слова: насилие, символическое насилие, социология насилия, критическая социология. 